\title{
Sustainable Development Goals (SDGs) Melalui Pembiayaan Produktif UMKM di Bank Syariah
}

\author{
*'Trimulato ${ }^{1}$, Nur Syamsu $^{2}$, Mega Octaviany $^{3}$ \\ ${ }^{1}$ UIN Alauddin Makassar, ${ }^{2}$ IAIN Dato Karama Palu, ${ }^{3}$ Universitas Gunadarma \\ *email korespondensi: tri.mulato@,uin-alauddin.ac.id
}

\begin{abstract}
The presence of law number 21 of 2008 drove shariah to be more developed, and accepted by the wider community. At present the market share of shariah banking has penetrated the figure of 5.8 percent. Shariah have financing products for the development of micro and medium small businesses. The bigest for financing product in shariah banking is still dominated by consumer financing, which is 42.80 percent. This research is qualitative in nature which describes the development of productive financing for SMEs at shariah banking, and the role of financing product to achieve sustainable development golas (SDGs). The results of this study indicate a decrease in the productive financing of working capital by 0.75 percent. Then the financing portion for SMEs of financing is still dominated by consumers, namely 69.14 percent or 139,408,000,000. Distribution of productive financing in the SMEs sector is very relevant and in line with the SDGs objectives, namely welfare and equity.
\end{abstract}

Keywords: SDGs, Financing Product For SMEs, and Shariah Banking

\begin{abstract}
Abstrak
Hadirnya undang-undang nomor 21 tabun 2008 mengantarkan bank syariab menjadi lebih berkembang, dan diterima kalangan luas. Saat ini pangsa pasar bank syariah telah menembus angka 5,8 persen. Bank syariah memiliki produk pembiayaan untuk perkembangan usaha kecil mikro dan menengah. Penyaluran pembiayaan di bank syariah masib didominasi pembiayaan konsumtifyaitu sebesar 42,80 persen. Penelitian ini bersifat kualitatif yang menguraikan tentang perkembangan pembiayaan produktif bank syariah untuk. UMKM dan peran pembiayaan untuk mencapai sustainable development goals (SDGs). Adapun basil dari penelitian ini menunjukkan adanya penurunan pada pembiayaan produktif modal kerja sebesar 0,75 persen. Kemudian porsi pembiayaan untuk. UMKM masih didominasi oleh konsumtif yaitu sebesar 69,14 persen atau sebesar 139.408.000.000. Penyaluran pembiayaan produktif pada sektor UMKM sangat relevan dan sejalan dengan tujuan SDGs yaitu kesejahteraan dan pemerataan.
\end{abstract}

Kata kunci: SDGs, Pembiayaan Produktif UMKM, Bank Syariah

\section{A. Pendahuluan}

Bank syariah dianggap seperti bank-bank pada umumnya, hal ini tidak terlepas dari akibat kurangnya pemahaman dari masyarakat serta minimnya edukasi yang dilakukan pihak perbankan syariah mengenai konsep baru ini yang diaplikasikan di dunia perbankan. Kurangnya pemahaman serta minimya edukasi yang mereka dapatkan memberikan persepsi yang berbeda mengenai produk bank 
syariah, hal ini tidak sesuai dengan realita sesungguhnya bahwa bank syariah merupakan bank yang mengadopsi nilai-nilai syariah Islam yang mengharamkan bunga. Padahal pemahaman masyarakat tentang keuangan syariah menjadi salah satu tolak ukur kebangkitan industri keuangan syariah di Indonesia.

Menurut hasil Survei Nasional Literasi dan Inklusi Keuangan (SNLIK) Otoritas Jasa Keuangan (OJK) tahun 2016, tingkat pengguna produk dan jasa keuangan syariah di Indonesia baru sebesar 11,06\%. Sedangkan indeks literasi keuangan syariah sebesar 8,11\%, hal ini mengindikasi pemahaman masyarakat terhadap produk-produk keuangan masih sangat rendah. Untuk itu, penelitian ini bertujuan untuk menganalisis kondisi bank syariah saat ini dalam mendukung UMKM halal dan untuk menganalisis potensi bank syariah dalam mendukung UMKM halal.Pada tahun 2014 Abdul Kadir Demanik selaku Staf Ahli Menteri UMKM bidang Penerapan Nilai Dasar Koperasi menyebutkan terdapat sekitar 57,9 juta pelaku UMKM di Indonesia dan jumlahnya terus meningkat. UMKM telah memberikan kontribusi pada PBD 58,92\% dan penyerapan tenaga kerja $97,3 \% .{ }^{1}$

Produk halal, termasuk di dalamnya bank syariah adalah produk-produk yang dinyatakan halal sesuai dengan ketentuan syariat Islam. Industri produk halal merupakan bagian dari ekonomi syariah yang dikembangkan pemerintah sejak sekitar tiga dasawarsa terakhir. Pada mulanya pengembangan ini menyentuh sektor jasa, yakni jasa keuangan. Perbankan syariah sendiri mulai menggeliat sejak 1990an. Tepatnya pada 1992, industri ini memasuki babak awal perjalanan ditandai dengan berdirinya bank umum syariah pertama di Indonesia, yakni Bank Muamalat. Sampai dengan Januari 2019, jasa keuangan syariah meraup pangsa 6,8 persen. Angka ini mungkin tampak kecil, tetapi sebetulnya terus menunjukkan pertumbuhan yang konsisten. Pemerintah juga mendirikan otoritas khusus salah satunya Badan Penyelenggara Penjaminan Produk Halal.

${ }^{1}$ Maya Novitasari, 'Optimalisasi Potensi Perbankan Syariah Di Indonesia Bagi Umkm Halal Dalam Mendukung Sustainable Development Goals’, Majalah Ekonomi, 24.1 (2019), 49-58. 
Kehadiran BPJPH bertujuan mengakomodir potensi pasar produk halal domestik yang terbilang besar, sejalan dengan menguatnya kecenderungan beragama penduduk Indonesia. Potensi perkembangan ekonomi syariah terutama didukung kesadaran masyarakat muslim Indonesia terhadap konsumsi barang dan jasa halal. Halal Economy and Strategy Roadmap 2018 menyebutkan, total konsumsi barang dan jasa halal Indonesia pada 2017 sekitar US\$218,8 miliar. Jumlah ini diperkirakan terus tumbuh rata-rata sebesar 5,3 persen dan mencapai US $\$ 330,5$ miliar pada 2025 mendatang. $^{2}$

Di sisi lain, meski proporsi usaha mikro mendominasi struktur perekonomian nasional, kesempatan atau akses mereka terhadap sumber pembiayaan yang berasal dari institusi perbankan dan keuangan formal masih sangat terbatas. Mereka dianggap sebagai kelompok yang tidak bankable. Karena itu, mendorong perkembangan lembaga keuangan mikro syariah (LKMS) telah menjadi kebutuhan yang sangat mendesak, sebagai upaya untuk memperbesar akses finansial bagi kelompok masyarakat marjinal tersebut. Apalagi secara konsep, ekonomi syariah memiliki keberpihakan yang sangat nyata terhadap pengembangan usaha mikro yang dimiliki oleh masyarakat.

Secara umum, pembiayaan mikro ini telah dilakukan oleh institusi ekonomi dan keuangan syariah melalui beberapa saluran, di antaranya koperasi syariah/Baytul Maal wat Tamwil (BMT), BPRS (Bank Pembiayaan Rakyat Syariah), dan BUS (Bank Umum Syariah)/UUS (Unit Usaha Syariah). Berdasarkan data yang ada, proporsi pembiayaan BPRS bagi usaha mikro, kecil dan menengah (UMKM) mencapai angka 84,8 persen, sementara proporsi pembiayaan UMKM BUS/UUS mencapai angka sekitar 64 persen. $^{3}$

Sistem perbankan Islam sudah seharusnya menjadi sarana pendukung untuk mewujudkan tujuan dari sistem sosial dan ekonomi Islam, oleh karenanya sistem perbankan Islam diharapkan memiliki tujuan kemakmuran ekonomi yang

${ }^{2}$ Evita Farcha Kamila, 'Peran Industri Halal Dalam Mendongkrak Pertumbuhan Ekonomi Indonesia Di Era New Normal', Jurnal Likuid, 1.1 (2020).

${ }^{3}$ Irfan Syauqi Beik and Laily Dwi Arsyianti, 'Ekonomi Pembangunan Syariah' Jakarta: PT RajaGrafindo Persada., 2017), p. 266 <https://opac.perpusnas.go.id/DetailOpac.aspx?id=969369>. 
meluas dengan tingkat kerja yang penuh dan tingkat pertumbuhan ekonomi yang optimum (economic well-being with full employment and optimum rate of economic growth), serta mewujudkan keadilan sosial-ekonomi dan distribusi pendapatan dan kekayaan yang merata (socio-economic justice and equitable distribution of income and wealth).

Peran perbankan syariah dalam mengembangkan usaha masyarakat terutama pada usaha mikro adalah dengan berpartisipasi memberikan pembiayaan kepada masyarakat untuk mengembangkan usahanya, baik usaha perorangan maupun usaha dalam bentuk kelompok, dengan harapan pertumbuhan dan perkembangan ekonomi masyarakat dari tahun-ketahun terus mengalami peningkatan. Oleh karenanya, perbankan syariah terus mendukung agar nasabah pembiayaan usaha mikro dapat terus mengalami peningkatan perekonomian.

BRI Syariah sebagai salah satu lembaga keuangan memiliki program pembiayaan yang sangat mendukung perkembangan usaha mikro. Salah satunya melalui Unit Mikro BRI Syariah iB yang memfasilitasi kebutuhan tambahan modal ataupun investasi. Dengan adanya program pembiayaan tersebut para pengusaha mikro dapat tambahan pinjaman modal sehingga dapat mengembangkan usahanya. ${ }^{4}$ Adapun Bank Mandiri Syariah berkomitmen untuk mendukung pengembangan UMKM sesuai ketentuan PBI No. 17/12/PBI/2015 mengenai Pemberian Kredit atau Pembiayaan oleh Bank Umum dan Bantuan Teknis dalam rangka Pengembangan Usaha Mikro, Kecil dan Menengah. Komitmen tersebut ditunjukkan dengan portofolio pembiayaan ke segmen UMKM per-posisi Agustus 2017, portofolio pembiayaan UMKM Mandiri Syariah mencapai 25,09\%, atau sekitar Rp14,5 triliun atau dari total pembiayaan senilai Rp57,86 triliun. Khusus untuk segmen mikro, per posisi Agustus 2017 Mandiri Syariah menyalurkan pembiayaan senilai Rp4,22 triliun. Pembiayaan tersebut diberikan kepada sekitar 74 ribu nasabah di seluruh Indonesia.(www.syariabmandiri.co.id).

${ }^{4}$ Muhamad Turmudi, 'PembiayaanMikro BRI Syariah: Upaya Pemberdayaan Dan Peningkatan UMKM Oleh BRI Syariah Cabang Kendari', Jurnal Studi Ekonomi Dan Bisnis Islam, 2017. 


\section{Pergeseran MDGs menjadi SDGs}

Pekerjaan Sosial mempunyai relevansi yang sangat kuat dengan masalah kemiskinan. Sudah berabad-abad profesi ini bergelut dan terlibat dalam penanganan kemiskinan. Secara historis profesi Pekerjaan Sosial boleh dikatakan lahir dari masalah kemiskinan. Profesi ini bahkan menempatkan masalah kemiskinan sebagai bidang utama yang ditangani Pekerjaan Sosial. Jika sangat menjunjung tinggi prinsip-prinsip Hak-Hak Azasi Manusia, Pekerjaan Sosial harus berada di garis depan dalam upaya mengatasi kemiskinan. MDGs yang kemudian bergeser ke SDGs merupakan tujuan bersama yang memerlukan pengalawan bersama baik vertical maupun horizontal. ${ }^{5}$

Rafiqoh Ferawati dalam penelitiannya yang berjudul Sustainable Development Goals di Indonesia: Pengukuran dan Agenda Mewujudkannya dalam Perspektif Ekonomi Islam menyebutkan berdasarkan analisis empat kuadran dimana membandingkan antara wilayah dengan pertumbuhan ekonomi tinggi namun mmemiliki dampak kerusakan lingkungan yang rendah ditemukan empat wilayah yaitu Jawa Timur, Jawa Tengah, Sumatera Utara dan Sumatera Selatan. Artinya keempat wilayah ini merupakan wilayah yang akan mampu mewujudkan SDGs, dimana pertumbuhan ekonomi yang dilakukan dengan tidak mengorbankan lingkungan di masa depan.

Perspektif Ekonomi Islam memandang bahwa perwujudan SDGs di Indonesia dapat dicapai. Hal ini terlihat dari hasil pengukuran dengan beberapa model yang diuji, DPK perbankan syariah selalu berpengaruh terhadap pengurangan kemiskinan. Artinya jika semakin banyak DPK perbankan syariah disalurkan dalam bentuk pembiayaan dan pinjaman kebaijkan maka akan semakin berkurang kemiskinan. Hal ini sejalan dengan prinsip keberadaan perbankan syariah selain profit oriented, juga social oriented yang dapat menjangkau lebih banyak masyarakat miskin. ${ }^{6}$

\footnotetext{
${ }^{5}$ Santoso Tri Ishartono; Raharjo, 'Sustainable Development Goals \& Transport', Sustainable Development Goals (SDGs) dan Pengentasan Kemiskinan, 2014.

${ }^{6}$ Rofiqoh Ferawati, 'Sustainable Development Goals Di Indonesia: Pengukuran Dan Agenda Mewujudkannya Dalam Perspektif Ekonomi Islam', Kontekstualita, 33.02 (2018), 143 $<$ https://doi.org/10.30631/kontekstualita.v35i02.512>.
} 
Nikmah Mentari and Franciska Mifanyira Sutikno dalam penelitiannya yang berjudul Sustainable Development Goals (SDGs) Principle Towards Sharia Business Unit Pre-Spin Off 2023 menyimpulkan bahwa bank jenis Unit Usaha Syariah (UUS) harus spin off menjadi menjadi Bank Umum Syariah (BUS), memisahkan diri dari induknya berdasarkan peraturan perundang-undangan dan kebijakan pemerintah untuk dapat berdiri sendiri dan mandiri. Unit Usaha Syariah wajib melakukan spin off dengan mendapatkan bantuan dari Bank Induk (Konvensional). Terkait penanganan masalah yang dapat terjadi seperti sumber dayar, skill, kondisi organisasi dan modal harus mendapat perhatian oleh induknya.

Oleh karena itu, bank Konvensional harus menyiapkan proses spin-off secara maksimal tidak hanya secara struktural organisasi tetapi juga bagaimana Unit Usaha Syariah dapat menghadapi era SDGs. Konvensional sebagai pemiliknya bertanggungjawab untuk proses spin off anak usahanya. Unit Usaha Syariah yang telah menjadi Bank Umum Syariah wajib menerapkan prinsip SDGS sebagai kewajiban sebagaimana diamanatkan oleh pemerintah dalam beberapa peraturan perundang-undangan dan peraturan. Bank Umum Syariah dapat berperan dengan membuat langkah-langkah persiapan manajemen, implementasinya layanan perbankan disesuaikan maksud dan tujuan SDGs serta pelaksanaan CSR juga dapat mendukung SDGS. ${ }^{7}$

Tujuan Pembangunan Berkelanjutan atau dalam bahasa Inggris dikenal sebagai Sustainable Development Goals disingkat dengan SDGs adalah 17 tujuan dengan 169 capaian yang terukur dan tenggat yang telah ditentukan oleh PBB sebagai agenda dunia pembangunan untuk kemaslahatan manusia dan planet bumi. Tujuan ini dicanangkan bersama oleh negara-negara lintas pemerintahan pada resolusi PBB yang diterbitkan pada 21 Oktober 2015 sebagai ambisi pembangunan bersama hingga tahun 2030. Tujuan ini merupakan kelanjutan atau pengganti dari Tujuan Pembangunan Milenium yang ditandatangani oleh

${ }^{7}$ Nikmah Mentari and Franciska Mifanyira Sutikno, 'Sustainable Development Goals (SDGs) Principle Towards Sharia Business Unit Pre-Spin Off 2023', UNIFIKASI : Jurnal Ilmu Hukum, 2019 $<$ https://doi.org/10.25134/unifikasi.v6i2.1866>. 
pemimpin-pemimpin dari 189 negara sebagai Deklarasi Milenium di markas besar PBB pada tahun 2000 dan tidak berlaku lagi sejak akhir 2015.

Pada bulan Agustus 2015, 193 negara menyepakati 17 tujuan berikut ini:

Tujuan 1 - Tanpa kemiskinan, Pengentasan segala bentuk kemiskinan di semua tempat. Tujuan 2 - Tanpa kelaparan Mengakhiri kelaparan, mencapai ketahanan pangan dan perbaikan nutrisi, serta menggalakkan pertanian yang berkelanjutan. Tujuan 3 - Kehidupan sehat dan sejahtera, Menggalakkan hidup sehat dan mendukung kesejahteraan untuk semua usia. Tujuan 4 - Pendidikan berkualitas, Memastikan pendidikan berkualitas yang layak dan inklusif serta mendorong kesempatan belajar seumur hidup bagi semua orang. Tujuan 5 Kesetaraan gender, Mencapai kesetaraan gender dan memberdayakan semua perempuan. Tujuan 6 - Air bersih dan sanitasi layak, Menjamin akses atas air dan sanitasi untuk semua. Tujuan 7 - Energi bersih dan terjangkau, Memastikan akses pada energi yang terjangkau, bisa diandalkan, berkelanjutan dan modern untuk semua. Tujuan 8 - Pekerjaan layak dan pertumbuhan ekonomi, Mempromosikan pertumbuhan ekonomi berkelanjutan dan inklusif, lapangan pekerjaan dan pekerjaan yang layak untuk semua. Tujuan 9 - Industri, inovasi dan infrastruktur, Membangun infrastruktur kuat, mempromosikan industrialisasi berkelanjutan dan mendorong inovasi. Tujuan 10 Berkurangnya kesenjangan, Mengurangi kesenjangan di dalam dan di antara negara-negara. Tujuan 11 - Kota dan komunitas berkelanjutan, Membuat perkotaan menjadi inklusif, aman, kuat, dan berkelanjutan. Tujuan 12 Konsumsi dan produksi yang bertanggung jawab, Memastikan pola konsumsi dan produksi yang berkelanjutan. Tujuan 13 - Penanganan perubahan iklim, Mengambil langkah penting untuk melawan perubahan iklim dan dampaknya. Tujuan 14-Ekosistem laut, Pelindungan dan penggunaan samudera, laut dan sumber daya kelautan secara berkelanjutan. Tujuan 15 - Ekosistem daratan, Mengelola hutan secara berkelanjutan, melawan perubahan lahan menjadi gurun, menghentikan dan merehabilitasi kerusakan lahan, menghentikan kepunahan keanekaragaman hayati. Tujuan 16 - Perdamaian, keadilan dan kelembagaan yang tangguh, Mendorong masyarakat adil, damai, dan inklusif. Tujuan 17 - Kemitraan untuk mencapai tujuan, menghidupkan kembali kemitraan global demi pembangunan berkelanjutan. ${ }^{8}$

Berakhirnya MDGs pada 2015 masih menyisakan sejumlah pekerjaan rumah yang harus diselesaikan pada periode Tujuan Pembangunan Berkelanjutan (Sustainable Development Goals/SDGs) yang akan dilaksanakan sampai dengan 2030. Tujuan Pembangunan Milenium (Millennium Development Goals/MDGs) yang telah dilaksanakan selama periode 2000-2015 memang telah membawa berbagai

8https://id.wikipedia.org/, 'Tujuan Pembangunan Berkelanjutan', Kementerian PPN / Bappenas, 2017 <https://id.wikipedia.org/wiki/Tujuan_Pembangunan_Berkelanjutan>. 
kemajuan. Sekitar 70 persen dari total indikator yang mengukur target MDGs telah berhasil dicapai oleh Indonesia. Akan tetapi, beberapa indikator yang mengukur target di bidang kesehatan masih cukup jauh dari capaian dan harus mendapatkan perhatian khusus.

Target yang belum tercapai di antaranya adalah tingkat kemiskinan nasional, angka kematian bayi, angka kematian ibu, prevalensi gizi buruk, prevalensi HIV dan AIDS serta beberapa indikator terkait lingkungan. Indonesia sebagai salah satu negara yang telah menyepakati penerapan tujuan pembangunan berkelanjutan (SDGs) berkomitmen untuk menyukseskan pelaksanaan SDGs melalui berbagai kegiatan dan telah mengambil langkah-langkah strategis. Sejumlah langkah yang telah ditempuh Indonesia sampai dengan akhir 2016 antara lain (i) melakukan pemetaan antara tujuan dan target SDGs dengan prioritas pembangunan nasional, (ii) melakukan pemetaan ketersediaan data dan indikator SDGs pada setiap target dan tujuan termasuk indikator proksi, (iii) melakukan penyusunan definisi operasional untuk setiap indikator SDGs, (iv) menyusun peraturan presiden terkait dengan pelaksanaan tujuan pembangunan berkelanjutan, dan (v) mempersiapkan rencana aksi nasional dan rencana aksi daerah terkait dengan implementasi SDGs di Indonesia. ${ }^{9}$

Tujuan Pembangunan Berkelanjutan (TPB)/Sustainable Development Goals (SDGs) atau Agenda 2030 telah dideklarasikan pada tanggal 25 September 2015, bertepatan dengan berlangsungnya United Nation General Assembly (UNGA) di kantor Perserikatan Bangsa-Bangsa - New York (Amerika Serikat. TPB/ SDGs yang cakupan dan substansinya selaras dengan Nawacita, terdiri atas 17 Tujuan dan 169 Target. Tujuan dan target tersebut menggambarkan visi dan ruang lingkup agenda pembangunan global yang inklusif dan multidimensi, yang akan menjadi panduan bagi komunitas global selama 15 tahun ke depan untuk mewujudkan kesejahteraan masyarakat global. Perserikatan Bangsa-Bangsa melalui Divisi Statistik UN-DESA telah mengeluarkan metadata 241 indikator (versi Maret 2016)

${ }^{9}$ Badan Pusat Statistik, Potret Awal Tujuan Pembangunan Berkelanjutan (Sustainable Development Goals) Di Indonesia, Katalog BPS, 2016. 
untuk mengukur pencapaian target TPB/ SDGs. Berdasarkan Metadata Indikator SDGs Global tersebut, telah dikembangkan Metadata Indikator TPB/SDGs Indonesia yang meliputi 17 TUjuan, 169 Target dan 320 Indikator. $^{10}$

Pada tanggal 25 September 2015 bertempat di Markas Besar Perserikatan Bangsa-Bangsa (PBB), para pemimpin dunia secara resmi mengesahkan Agenda Tujuan Pembangunan Berkelanjutan (Sustainable Development Goals) sebagai kesepakatan pembangunan global. Kurang lebih 193 kepala negara hadir, termasuk Wakil Presiden Indonesia Jusuf Kalla turut mengesahkan Agenda SDGs. Dengan mengusung tema "Mengubah Dunia Kita: Agenda 2030 untuk Pembangunan Berkelanjutan", SDGs yang berisi 17 Tujuan dan 169 Target merupakan rencana aksi global untuk 15 tahun ke depan (berlaku sejak 2016 hingga 2030), guna mengakhiri kemiskinan, mengurangi kesenjangan dan melindungi lingkungan. SDGs berlaku bagi seluruh negara (universal), sehingga seluruh negara tanpa kecuali negara maju memiliki kewajiban moral untuk mencapai tujuan dan target SDGs.

SDGs dirancang secara partisipatif berbeda dari pendahulunya Millenium Development Goals (MDGs), SDGs dirancang dengan melibatkan seluruh aktor pembangunan, baik itu Pemerintah, Civil Society Organization (CSO), sektor swasta, akademisi, dan sebagainya. Kurang lebih 8,5 juta suara warga di seluruh dunia juga berkontribusi terhadap Tujuan dan Target SDGs. Tidak Meninggalkan Satu Orangpun (Leave No One Behind) Prinsip utama SDGs. Dengan prinsip tersebut setidaknya SDGs harus bisa menjawab dua hal yaitu, Keadilan Prosedural yaitu sejauh mana seluruh pihak terutama yang selama ini tertinggal dapat terlibat dalam keseluruhan proses pembangunan dan Keadilan Subtansial yaitu sejauh mana kebijakan dan program pembangunan dapat atau mampu menjawab persoalanpersoalan warga terutama kelompok tertinggal. ${ }^{11}$

\footnotetext{
${ }^{10}$ Bappenas, Ringkasan Metadata Tujuan Pembangunan Berkelanjutan (TPB)/ Indikator Sustainable Development Goals (SDGs) Indonesia, Kementerian PPN / Bappenas, 2017.

${ }^{11}$ sdg2030indonesia, 'Agenda Tujuan Pembangunan Berkelanjutan (Sustainable Development Goals)', 2019 <https://www.sdg2030indonesia.org/page/8-apa-itu>.
} 


\section{B. Metode Penelitian}

Penelitian ini bersifat deskriptif kualitatif yang artinya menggambarkan suatu subyek penelitian. Dalam hal ini adalah pertumbuhan pembiayaan produktif pada sektor mikro di Bank Syariah. Kemudian desain peran dari pembiayaan produktif UMKM di bank syariah tersebut dalam pencapaian sustanaible development Goals (SDGs). Konsep keuangan syariah yang sejalan dengan tujuan SDGs.

Jenis data yang digunakan dalam tulisan ini adalah data kualitatif yang bersumber dari data primer dan data sekunder. Data primer berupa sumber data yang langsung memberikan data kepada peneliti atau data yang diperoleh langsung dari lapangan (objek penelitian), sedangkan data sekunder adalah sumber data yang tidak langsung memberikan data kepada pengumpul data (peneliti) atau data yang diambil peneliti sebagai pendukung atas penelitian secara ilmiah yaitu dengan melakukan studi pustaka (penelusuran melalui buku, artikel, jurnal, majalah, internet dan sumber lainnya). Data-data yang digunakan antara lain teori-teori dari berbagai literatur yang berkaitan dengan SDGs dan lembaga keuangan syariah serta data yang diperoleh dari Otoritas Jasa keuangan dan sumber data lainnya.

Batasan dalam tulisan ini difokuskan pada perkembangan produk pembiayaan produktif pada sektor UMKM di Bank Syariah, serta pola SDGs. Keduanya sejalan dalam mencapai tujuan untuk kesejahteraan. Dengan menyesuaikan pola dari pembiayaan produktif bank syariah dalam kegiatannya mendukung dan sejalan dengan SDGs yang terus dicanangkan. Teknik pengumpulan data yang diperlukan dalam tulisan ini adalah dengan menggunakan beberapa metode yaitu studi kepustakaan untuk menggali dasar-dasar teori yang terkait dengan Sustainable Development Goals (SDGs), ekonomi Islam, lembaga keuangan Islam, serta perkembangan pembiayaan produktif pada sektor riil UMKM di bank syariah. Setiap data yang didapatkan dari berbagai sumber diamati dan dianalisa terkait dengan kondisi pertumbuhan dari pembiayaan produktif UMKM di bank syariah, serta terkait data tentang peran dan tujuan dari SDGs yang sejalan dengan keberadaan lembaga keuangan syariah yang telah ada sebelumnya. 
Metode analisis data yang digunakan adalah dengan menggunakan pendekatan kualitatif deskriptif yaitu dengan cara memaparkan perkembangan dari pembiayaan pada sektor produktif UMKM di bank syariah, serta menguraikan konsep Sustanaible Development Goals (SDGs) yang saat ini terus diupayakan oleh pemerintah. Kemudian tujuan dari SDGs yang sejalan dengan tujuan dari lembaga keuangan syariah. Keberadaan lembaga keuangan syariah memiliki peran yang kuat dalam pencapaian SDGs. Pembiayaan produktif UMKM bank syariah sebagai upaya tujuan SDGs.

\section{Hasil dan Pembahasan}

\section{Bank Syariah dan SDGs}

Bank syariah yang sejatinya melekat pada identitasnya sebagai lembaga keuangan syariah yang akan mendukung pertumbuhan sektor riil khususnya pada kegiatan ekonomi produktif, belum menjadikan porsi pembiayaan pada kegiatan produktif. Sebagaimana data berikut:

Tabel 1.1

Porsi Pembiayaan di Bank Syariah Periode April 2018

\begin{tabular}{|c|c|c|c|}
\hline NO & Tujuan Pembiayaan & Besar Pembiayaan & Porsi Pembiayaan \\
\hline 1 & Modal Kerja & 97.569 & $33,91 \%$ \\
\hline 2 & Investasi & 67.008 & $23,29 \%$ \\
\hline 3 & Konsumsi & 123.178 & $42,80 \%$ \\
\hline 4 & Jumlah & $\mathbf{2 8 7 . 7 5 5}$ & $\mathbf{1 0 0} \%$ \\
\hline
\end{tabular}

Sumber: Statistik Perbankan Syariah (OJK,2018)/ Data diolah

*Miliar Rupiah

Dari data di atas menunjukkan bahwa penyaluran pembiayaan di bank syariah pada periode April Tahun 2018 masih didominasi untuk pembiayaan untuk keperluan konsumtif yaitu sebesar 42,80 persen atau sebesar 123.178.000.000.000. Lalu porsi kedua yaitu penyaluran pembiayaan modal kerja sebesar 33,91 persen, dan terakhir porsi untuk penyaluran pembiayaan pada investasi sebesar 23,29 persen. Perlu ada kesunggguhan dari perbankan syariah untuk bisa mendukung sektor rill khususnya kegiatan produktif mikro kecil dan menengah. Untuk menjaga konsistensinya sebagai lembaga yang akan menopang dan berkontribusi bagi negara.

Konsep muamalah yang dibagun dalam ekonomi Islam bertujuan untuk mensejahterahkan seluruh ummat manusia, termasuk menciptakan keadilan, serta 
pencapaian falah, yaitu kebahagian yang harus merata dan dapat dirasakan oleh semua manusia. Dalam ekonomi Islam kemerataan menjadi penting, harta yang tidak boleh dinikmati hanya segelintir orang saja. Tetapi upaya harta terus berputar dan bisa didistribusikan melalui kegiatan ekonomi, agar semua orang punya peluang yang sama untuk mencapai kesajahteraan ekonomi. Kesejahteraan yang dikehendaki dalam ekonomi Islam ini sejalan dengan Sustainable Development Goals (SDGs), yang saat ini juga menjadi tujuan pembangunan secara global. SDGs sendiri memiliki 17 tujuan dan 169 pencapaian sesuai dengan ketentuan PBB.

Tujuan dari SDG's juga dapat dicapai dengan melibatkan banyak lembaga, termasuk diantaranya yaitu lembaga keuangan syariah. Hal ini karena pencapain SDGs sejalan dengan tujuan yang dicapai dalam konsep ekonomi Islam. Ada kesamaan dalam tujuan dan sejalan dengan apa yang ingin dicapai keduanya. United Nations Development Program (UNDP) Indonesia mengadakan Roundtable Discussion dengan Tema: "Leveraging Innovative Financing for Development: Islamic Banking \& Finance for SDGs" mengundang Tazkia untuk berbagi pengalaman penerapan ekonomi dan keuangan Syariah di Indonesia pada 25 September 2018. Murniati Mukhlisin, Ketua STEI Tazkia, hadir menyampaikan betapa Maqashid Syariah memilki tujuan yang sama dengan Sustainable Development Goals (SDGs) yang dituju oleh UNDP.

Murniati juga menjelaskan besarnya potensi keuangan syariah di dunia. “Berbagai negara di Eropa seperti Perancis, Jerman, Luxembourg, UK terlebih lagi negara Muslim seperti Iran, Malaysia, UAE, Arab Saudi dan Indonesia memiliki perhatian besar terhadap perkembangan keuangan syariah yang tampak dari pertumbuhan aset", "Dengan dukungan dari UNDP, regulator, perbankan syariah, FinTech, dunia pendidikan, dan lembaga sosial, diharapkan tujuan mulia ekonomi syariah yang juga senada dengan SDGs dapat tercapai dengan sebaik mungkin". 12

12http://mysharing.co/id, 'SDGs Sesuai Dengan Keuangan Syariah', 2019 $<$ http://mysharing.co/sdgs-sesuai-dengan-keuangan-syariah/ $>$. 
Perkembangan ekonomi syariah telah mencapai pertumbuhan secara global dan menyentuh banyak aspek, baik di bidang keuangan komersial seperti perbankan, pasar modal, asuransi maupun di bidang keuangan semi komersial dan sosial seperti Lembaga Keuangan Mikro Syariah di Koperasi Syariah dan Baitul Mal wat Tamwil, maupun lembaga keuangan sosial seperti pengelola zakat, infak, sedekah dan wakaf.

Peranan sosial ekonomi dan keuangan Islam ini dipandang sejalan dan mampu berkontribusi mencapai tujuan Sustainable Development Goals/SDGs. Dalam rangka mengejar agenda 2030, UNDP Indonesia telah mulai melakukan sejumlah kerja untuk menggunakan keuangan Islam dalam kerangka kerja mereka. Salah satu fokus kegiatan UNDP Indonesia yang berkaitan dengan keuangan Islam adalah upaya meningkatkan kapasitas yang diperlukan pada level Negara, regional, maupun internasional terutama dalam hal keuangan sosial. UNDP telah menjalin kerjasama penelitian dengan Islamic Development Bank Islamic Research and Training Institute (IRTI). ${ }^{13}$

Menteri Keuangan (Menkeu) Sri Mulyani Indrawati membuka The 2nd Annual Islamic Finance Conference yang diselenggarakan pada tanggal 23-24 Agustus 2017 di Hotel Royal Ambarrukmo, Yogyakarta. Konferensi ini mengangkat tema "The Role of Islamic Finance in Eradicating Poverty and Income Inequality". Di acara tersebut Menkeu menjelaskan saat ini dunia memiliki tujuan baru, yaitu menciptakan pembangunan yang berkelanjutan (Sustainable Develoment GoalsSDG). Dalam hal ini peran keuangan syariah sangat penting, sesuai dengan tujuan dari negara-negara Islam untuk memberantas kemiskinan dan penyetaraan pendapatan. "Nilai-nilai dalam Islam sejalan dengan tujuan untuk mencapai SDG's, namun diperlukan pemikiran-pemikiran yang inovatif dan kreatif untuk mengembangkan instrumen keuangan syariah. ${ }^{14}$

\footnotetext{
${ }^{13}$ Andri Soemitra, Peran Pemberdayaan Masyarakat Oleb Lembaga Keuangan Mikro Syariah Dalam Perspektif Sustainable Development Goals (SDGs), 2018.

${ }^{14}$ https://www.kemenkeu.go.id/, 'Menkeu: Nilai-Nilai Islam Sejalan Dengan SDG', 2017 $<$ https://www.kemenkeu.go.id/publikasi/berita/menkeu-nilai-nilai-islam-sejalan-dengan-sdg/>.
} 
Sebagai salah satu lembaga otoritas, Otoritas Jasa Keuangan (OJK) memiliki peran untuk mensukseskan SDG's melalui program keuangan berkelanjutan (sustainable financing). Program ini dilakukan melalui kerja sama berbagai pihak sehingga tercipta dukungan pembiayaan kepada lembaga yang menerapkan prinsip keuangan berkelanjutan. Program keuangan berkelanjutan tidak hanya berupaya untuk meningkatkan porsi pembiayaan namun juga untuk meningkatkan daya tahan dan daya saing lembaga jasa keuangan. OJK bekerjasama dengan beberapa lembaga terkait telah menyusun Roadmap Keuangan Berkelanjutan. Roadmap ini bertujuan untuk menjabarkan kondisi yang ingin dicapai terkait keuangan yang berkelanjutan di Indonesia dalam jangka menengah (2015-2019) dan panjang (2015-2024) bagi industri jasa keuangan yang berada di bawah pengawasan OJK, serta untuk menentukan dan menyusun tonggak perbaikan terkait keuangan berkelanjutan.

Roadmap tersebut di atas akan menjadi acuan bagi OJK dan pelaku industri jasa keuangan serta pihak-pihak lain yang memiliki kepentingan untuk mendukung pembangunan berkelanjutan terutama pemerintah, pelaku industri maupun lembaga internasional. OJK memastikan terdapat delapan perbankan nasional baik Badan Usaha Milik Negara (BUMN) maupun swasta yang siap menerapkan sistem keuangan berkelanjutan ysitu Bank Mandiri, Bank BRI, Bank BNI, Bank BCA, Bank Muamalat, Bank BJB, Bank Arta Graha dan Bank BRI Syariah. Penerapan keuangan berkelanjutan di Indonesia akan dilakukan secara bertahap. Setelah roadmap dicanangkan, Selama dua tahun proyek ini bertujuan untuk meningkatkan awareness di industri keuangan. ${ }^{15}$

Bank syariah sebagai lembaga keuangan syariah yang punya peran sebagai lembaga intermediasi yang banyak melakukan transaksi dengan masyarakat. Sebaiknya bank syariah dapat berkontribusi dalam pencapaian pembangunan berkelanjutan (Sustanaible Development Goals/SDGs). Khususnya dalam tercapainya kesejahteraan di tengah masyarakat secara merata. Kegiatan pembiayaan pada

\footnotetext{
${ }^{15}$ Neneng Hayati, Erwin Yulianto, and Safdinal, 'Peranan Keuangan Berkelanjutan Pada Industri Perbankan Dalam Mendukung Sustainable Development Goals', Jurnal Akuntansi Bisnis Dan Ekonomi, 6.1 (2020), 173-90.
} 
sektor produktif pada UMKM dapat dilakukan di Bank Syariah. Sejalan dengan konsep dalam ekonomi Islam bahwa harta tidak sekedar dinikmati dan berputar pada golongan tertentu. Perlu dilakukan kegiatan melalui kegiatan riil khususnya pada sektor riil UMKM untuk mewujudkan kesejahteraan yang merata.

Muhammad Fardan Ngoyo dalam penelitiannya menyimpulkan bahwa tujuan pembangunan berkelanjutan bukanlah sesuatu yang taken for granted yang serta merta harus diikuti tanpa pernah memikirkan bagaimana dampak dan kontribusinya bagi rakyat banyak. Pada intinya proses pembangunan berkelanjutan yang berdasarkan pada tiga komponen yakni sosial, lingkungan, dan ekonomi yang saling terhubung. Tercapainya tujuan dan target SDGs yang akan berlaku mulai tahun 2015 dan akan ditargetkan akan tercapai pada 2030 merupakan pekerjaan yang tidak mudah dan membutuhkan upaya yang serius dari pemerintah.

Selain itu, upaya serius dari pemerintah belumlah cukup bila tidak ada dukungan dari berbagai pihak yang menyokong terlaksananya tujuan tersebut. Partisipasi berbagai pihak dibutuhkan dalam upaya memberikan kontribusi yang positif bagi pembangunan berkelanjutan. Pemerintah perlu merangkul pihak lain seperti organisasi masyarakat sipil (NGO), masyarakat, pelaku usaha, hingga kaum muda dalam berpatisipasi dan memberikan kontribusi sesuai dengan kapabilitas masing-masing. Karena, tujuan utama digagasnya pembangunan berkelanjutan adalah bagaimana pembangunan yang mendatangkan kesejahteraan dapat dipertahankan untuk masa depan atau generasi mendatang. ${ }^{16}$

\section{Perkembangan Pembiayaan Produktif di Bank Syariah}

Tabel 3.1

Pertumbuhan Pembiayaan Produktif UMKM Bank Syariah 2018

\begin{tabular}{|c|c|c|c|c|}
\hline No & Jenis Pembiayaan & Desember 2017 & Desember 2018 & Pertumbuhan \% \\
\hline $\mathbf{1}$ & Modal Kerja UMKM & 37.868 & 37.583 & -075 \\
\hline $\mathbf{2}$ & Investasi UMKM & 21.111 & 24.646 & 16,74 \\
\hline $\mathbf{3}$ & Konsumsi UMKM & 119.021 & 139.408 & 17,13 \\
\hline $\mathbf{4}$ & Total & 178.000 & 201.637 & $\mathbf{1 3 , 2 8}$ \\
\hline
\end{tabular}

Sumber: Otoritas Jasa Keuangan (Statistik Perbankan Syariah Desember 2018) Data

Diolah *Dalam Milyar Rupiah

${ }^{16}$ Muhammad Fardan Ngoyo, 'Mengawal Sustainable Development Goals (SDGs); Meluruskan Orientasi Pembangunan Yang Berkeadilan', Sosioreligius, 2015. 
Data di atas menunjukkan penyaluran pembiayaan yang diberikan bank syariah pada sektor UMKM pada periode desember 2017 sampai dengan desember 2018. Data diatas menunjukkan pada pembiayaan bank syariah untuk sektor UMKM terbagi atas dua yaitu produktif dan konsumtif. Penyaluran pembiayaan UMKM produktif terdiri dari dua yaitu Modal kerja dan Investasi, adapun satu lagi adalah pembiayaan konsumtif. Dari data menunjukkan adanya pertumbuhan pembiayaan untuk UMKM terbesar adalah untuk konsumsi yang tumbuh sebesar 17,13 persen.

Adapun pembiayaan UMKM produktif mengalami penurunan pada pembiayaan modal kerja sebesar 0,75 persen, sedangkan pembiayaan UMKM untuk investasi tumbuh sebesar 16,74 persen. Jika kita lihat data diatas penyaluran pembiayaan untuk UMKM masih didominasi untuk konsumsi bukan pembiayaan produktif. Porsi pembiayaan untuk UMKM konsumsi sebesar 139.408.000.000. dari total penyaluran pembiayaan UMKM sebesar 201.637.000.000 atau sebesar 69,14, sedangkan porsi untuk pembiayaan UMKM produktif hanya sebesar 30,86 persen.

Perlu ada upaya dari bank syariah untuk lebih memperhatikan dan berkomitmen untuk berkontribusi dalam mengembangkan sektor riil UMKM, salah satu cara dengan memperbesar porsi pembiayaan untuk produktif bukan konsumtif. Hal ini perlu dilakukan dalam rangka mengembangkan sektor riil membuka akses terbukanya usaha-usaha mikro baru agar terus berkembang. Kehadiran bank syariah yang tidak sekedar sebagai lembaga intermediasi, tetapi juga memjunjung spirit dalam pendistribusian pendapatan sebagaimana prinsip ekonomi Islam. Selain itu aspek moral dan etika dalam ekonomi Islam juga perlu diaplikasikan di bank syariah, unsur peduli dan saling menolong bagi yang membutuhkan juga perlu dilakukan khususnya para pengusaha mikro.

\section{Pembiayaan Produktif Bank Syariah Untuk UMKM: upaya mencapai sustainable development goals (SDGs).}

Sustanaible Development Goals (SDGs) atau pembangunan yang berkelanjutan yang telah disepakati untuk dijalankan memiliki 17 tujuan pokok yang ingin 
dicapai. Kesejahteraan dalam ekonomi menjadi bagian dari tujuan SDGs yang akan dicapai sampai tahun 2030. Dalam mencapai tujuan-tujuan itu melibatkan banyak pihak untuk bisa meralisasikannya, diantara lembaga relevan dan sejalan dengan tujuan SDGs adalah lembaga keuangan mikro syariah. Keduanya memiliki tujuan yang sama yaitu bisa memberikan kesejahteraan kepada masyarakat. SDGs juga memiliki tujuan agar terjadi terjadi pemerataan dalam ekonomi, hadirnya lembaga keuangan mikro syariah memberikan akses bagi pemerataan layanan keuangan bagi masyarakat kelas bawah.

Salah satu pencapain yang ingin dicapai dalam SDGs dalam bidang ekonomi yaitu kesejahteraan dan pemerataan kesejahteraan. Bank syariah menjadi bagian yang dapat mewujudkan tujuan SDGs tersebut, dengan meningkatkan perannya sebagai lembaga keuangan syariah yang banyak berhubungan dengan masyarakat. Bank syariah dapat menyalurkan pembiayaan produktif untuk usaha Mikro Kecil dan Menengah (UMKM). Melalui pembiayaan produktif untuk UMKM bank syariah tidak hanya memberikan layanan akses keuangan tetapi juga memberikan peluang untuk berkembangnya perekonomian dari masyarakat bawah. Pembiayaan produktif yang diberikan kepada para pelaku UMKM akan meningkatkan pendapatan ekonomi dan meningkatkan kesejahteraan. Perputaraan ekonomi tidak hanya dinikmati oleh para pengusaha besar.

Peran lembaga keuangan syariah dalam mencapai SDGs sangat dibutuhkan khususnya untuk menjangkau masyarakat secara keseluruhan. Bentuk peran dari lembaga keuangan mikro syariah untuk mencapai SDGs yaitu memberikan modal usaha untuk kelas kecil dan menengah dalam rangka mengngkatkan taraf ekonomi semua masyarakat. Kemudian memberikan akses layanan yang baik dan berkualitas bagi setiap masyarakat yang ingin melakukan akses pada produkproduk keuangan, termasuk memberikan produk investasi. Lembaga keuangan mikro syariah harus memahamkan dan mengenalkan bentuk investasi kepada semua masyarakat untuk bisa memperoleh tambahan dan meningkatkan pendapatan ekonomi. 


\section{Simpulan}

Pertumbuhan pembiayaan produktif untuk UMKM yang disalurkan bank syariah pada periode desember 2017 sampai dengan desember 2018 mengalami penurunan sebesar 0,75 persen pada modal kerja, dan mengalami peningkatan pada investasi yaitu sebesar 16,74 persen. Adapun penyaluran pembiayaan UMKM yang bersifat konsumtif tumbuh sebesar 17,14 persen. Dari total penyaluran pembiayaan bank syariah untuk UMKM 201.637.000.000 masih didominasi oleh pembiayaan konsumtif, atau sebesar 69,14 persen.

Bank syariah memiliki pembiayaan produktif UMKM yang dapat berperan mewujudkan kesejahteraan dan pemerataan. Melalui pembiayaan produktif UMKM bank syariah tidak hanya memberikan akses layanan keuangan kepada masyarakat, tetapi juga memberikan peluang berkembangnya UMKM. Pembiayaan produktif UMKM bank syariah akan meningkatkan pendapatan, ekonomi, dan kesejahteraan para pelaku UMKM. Kesejahteraan yang sama menjadi tujuan dari SDGs.

\section{Daftar Pustaka}

Andri Soemitra, Peran Pemberdayaan Masyarakat Oleh Lembaga Kenangan Mikro Syariah Dalam Perspektif Sustainable Development Goals (SDGs), 2018

Badan Pusat Statistik, Potret Awal Tujuan Pembangunan Berkelanjutan (Sustainable Development Goals) Di Indonesia, Katalog BPS, 2016

Bappenas, Ringkasan Metadata Tujuan Pembangunan Berkelanjutan (Tpb)/ Indikator Sustainable Development Goals (SDGs) Indonesia, Kementerian PPN / Bappenas, 2017

Beik, Irfan Syauqi, and Laily Dwi Arsyianti, 'Ekonomi Pembangunan Syariah' (Jakarta: PT RajaGrafindo Persada., 2017), p. 266 <https:/ /opac.perpusnas.go.id/DetailOpac.aspx?id=969369>

Evita Farcha Kamila, 'Peran Industri Halal Dalam Mendongkrak Pertumbuhan Ekonomi Indonesia Di Era New Normal', Jurnal Likuid, 1.1 (2020)

Ferawati, Rofiqoh, 'Sustainable Development Goals Di Indonesia: Pengukuran Dan Agenda Mewujudkannya Dalam Perspektif Ekonomi Islam', Kontekstualita, 33.02 (2018), 143 <https://doi.org/10.30631/kontekstualita.v35i02.512> 
Hayati, Neneng, Erwin Yulianto, and Safdinal, 'Peranan Keuangan Berkelanjutan Pada Industri Perbankan Dalam Mendukung Sustainable Development Goals', Jurnal Akuntansi Bisnis Dan Ekonomi, 6.1 (2020), 173-90

http://mysharing.co/id, 'SDGs Sesuai Dengan Keuangan Syariah', 2019 $<$ http:// mysharing.co/sdgs-sesuai-dengan-keuangan-syariah/>

https://www.kemenkeu.go.id/, 'Menkeu: Nilai-Nilai Islam Sejalan Dengan SDG', $2017<$ https://www.kemenkeu.go.id/publikasi/berita/menkeu-nilai-nilaiislam-sejalan-dengan-sdg/>

Ishartono; Raharjo, Santoso Tri, 'Sustainable Development Goals \& Transport', Sustainable Development Goals (SDGs) dan pengentasan kemiskinan, 2014

Mentari, Nikmah, and Franciska Mifanyira Sutikno, 'Sustainable Development Goals (SDGs) Principle Towards Sharia Business Unit Pre-Spin Off 2023', UNIFIKASI: Jurnal Ilmu Hukum, 2019 <https://doi.org/10.25134/unifikasi.v6i2.1866>

Muhamad Turmudi, 'PembiayaanMikro BRI Syariah: Upaya Pemberdayaan Dan Peningkatan UMKM Oleh BRI Syariah Cabang Kendari', Jurnal Studi Ekonomi Dan Bisnis Islam, 2017

Ngoyo, Muhammad Fardan, 'Mengawal Sustainable Development Goals (SDGs); Meluruskan Orientasi Pembangunan Yang Berkeadilan’, Sosioreligius, 2015

Novitasari, Maya, 'Optimalisasi Potensi Perbankan Syariah Di Indonesia Bagi Umkm Halal Dalam Mendukung Sustainable Development Goals', Majalab Ekonomi, 24.1 (2019), 49-58

sdg2030indonesia, 'Agenda Tujuan Pembangunan Berkelanjutan (Sustainable Development Goals)', 2019 <https://www.sdg2030indonesia.org/page/8-apaitu>

Solihin, Khabib, 'Analisis Kebijakan Sertifikasi Produk Halal dalam Perspektif Perlindungan Kemaslahatan Umat', Islamic Review: Jurnal Riset Dan Kajian Keislaman, $2020<$ https://doi.org/10.35878/islamicreview.v9i1.188> 
Sustainable Development Goals (SDGs) Melalui ... 